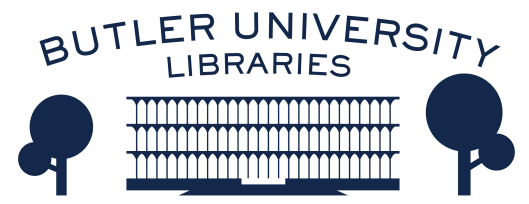

Journal of Hindu-Christian Studies

Volume 6

Article 11

January 1993

\title{
Viewpoints: Environment, Spirituality and Women
}

J. Josephine

Follow this and additional works at: https://digitalcommons.butler.edu/jhcs

Part of the Religion Commons

\section{Recommended Citation}

Josephine, J. (1993) "Viewpoints: Environment, Spirituality and Women," Journal of Hindu-Christian Studies: Vol. 6, Article 11.

Available at: https://doi.org/10.7825/2164-6279.1080

The Journal of Hindu-Christian Studies is a publication of the Society for Hindu-Christian Studies. The digital version is made available by Digital Commons @ Butler University. For questions about the Journal or the Society, please contact cbauman@butler.edu. For more information about Digital Commons @ Butler University, please contact digitalscholarship@butler.edu. 


\title{
Environment, Spirituality and Women
}

\author{
J. Josephine, University of Madras
}

MODERN-DAY HOMES, offices and places of amusement are decorated with portraits of beautiful landscapes, flora and fauna. In some cases the walls are adorned with beautiful and exotic wallpapers to get a feeling of staying or living in the natural environs. Roadside hawkers are very busy selling beautiful pictures of nature in all its glory as they attract shoppers. People living in concrete jungles in big cities and towns crave for a refreshing glimpse of nature to enliven their drooping spirits.

There is also this culture of artificial plants and flowers. A wide variety of plants and flowers are available in the market to decorate homes, work places and even places of worship. The synthetic culture is fast catching on in a world where people hardly have the time and resources to tend and care for natural plants and flowers. What has happened to human ethos? Why are people sliding into a synthetic life and culture? Why is the face of the Earth changing? Is it the same Earth that we are living in that was created by God in all its glory and beauty? Such were some of the questions that were raised at the 'Rio de Janeiro Earth Summit' in June 1992. Leaders, scientist, NGO members and media persons from the developed and the developing countries got together to pay serious attention to the problems of the environment. The objective was to explore ways and means to help restore the balance between nature and humankind.

The beautiful story of creation narrated in the scripture says 'God called the dry land Earth ... And God saw that it was Good' (Gn.1, 10-13) The narrative of creation and the birth of the Earth vividly presents the richness of the Earth, and the literary beauty of the verses stresses God's creative activity and his mercy in providing the Earth with every living thing from the waters, the sky and the earth, 'And God said, let the waters bring forth swarms of living creatures ...' (Gn.1, 20-25). God made the Earth bountiful to provide abundantly. But the image of the Earth that is dominant today is one of barrenness and poverty. The two great famines in recent times in Ethiopia and Somalia are testimony to the existing situation. The horrifying images of dry and parched land and the skeletal, formless figures of human beings (mostly of women and children) starved of food for months on end are signs of nature and man perishing together. Even though initially it appeared to be a natural calamity, soon it was realised that there is a politics of hunger and famine. The ethnic conflicts and group clashes were the real cause of starvation, sufferings and death. The politics of power or man's craze for superiority has dehumanised the world. War is another name for power. While war is a challenge to man it is a nightmare to women as it destroys peace, hope, life and relationships. Six decades ago Mahatma Gandhi asked: 'How can we be non-violent to nature unless the principle of non-violence becomes central to the ethos of human culture?' It is the epidemic of violence that is eating away the green in human life and nature.

God created man by saying, '...Let us make man in our image, after our likeness ...'(Gn.1, 26-27). Man was created in God's own likeness and image as the crowning glory of creation. And God gave man dominion over all created things. In turn man was expected to be thankful to God for his abundant blessings and be a responsible custodian of God's creation and enable the whole world to flower into fullness by being in harmony with his own kind and the rest of creation. 
The 'canticle of the creatures' Of St. Francis of Assisi praising God for the whole of creation is a beautiful manifestation of man's oneness with god and his harmony with nature, the vertical and horizontal dimensions of man's relationship with the creator and his creation. The fruit of this relationship is man becoming an instrument of God's Love and Peace. This was the motto of the life of St. Francis.

Peace which stands for shalom, is a Hebrew concept for the wholeness of life. In actuality it is the negation of the actualisation of this wholeness or fullness that causes war. The dangers of war are heightened by intolerance, national chauvinism and a failure to understand varying points of view. In fact it was after the second world war that the realisation that human beings can do irreparable damage to our basic life support systems of land, water, flora, fauna and atmosphere started receiving greater scientific and public attention. The nuclear holocausts of Hiroshima and Nagasaki (August 1945) are a mute testimony to the horrors of war.

The development of science and technology has made man arrogant and oppressive. It is also true that scientific inventions and technological developments are put to use mindlessly without care for the welfare of all humanity. Barry Commoner, an American environmentalist, asserts that changes in the technology of production in America after world war II are the root cause of modern environmental pollution. The prevailing dominance of private interests over public interests, combined with an insatiable industrial development led to not paying attention to the safety measures to be adopted and the disposal of industrial waste. The great Bhopal gas tragedy (3 Dec. 1984) is still fresh in the minds of people. The gas leak (Methyl Gisocyonate), which occurred in the U.S.-based multinational company Union Carbide in Bhopal, killed more than 2000 persons and more than 20,000 people were treated in hospital. The toxic chemical which shrouded the city became an open gas chamber for may innocent persons. The accident was a clear case of the multinational companies setting up a unit in a Third World country and not paying heed to proper industrial safety measures. Now to add to the agony, the most unfortunate thing is that the accident victims have not been paid the compensation even nine years after the accident. The poor and the less fortunate are neglected and there is no value for their lives. It is the rich nations which have caused the greatest damage to the earth. In fact it is said that president Fidel Castro of Cuba pointed out at the Rio Earth Summit that the ecological debt which the industrialised nations owe to the developing countries far exceeds the economic debt which the latter owe to the former. As the Vatican II Council document stresses 'everyone should look upon his neighbour (without any exception) as another self, bearing in mind above all his life and means necessary for living it in a dignified way lest he follow the example of the rich man who ignored Lazarus the poor man' (The Dignity of the Human Person p.928).

Despite all the schemes, programmes and developments at the international and national levels the condition of the poor is deteriorating and they are being driven to the periphery. The vulnerability of the poor countries is also exploited by the rich nations and they have converted the developing countries into a dumping or testing ground for their nuclear, scientific and technological tests. Over the past two decades the pattern that has emerged was the recognition that major environmental threats were caused by globally powerful institutions like multinational development banks and multinational corporations. The World Bank, which reaches every city, town and village in the developing countries, decides the feature of human and environmental concerns. Such organisations do not really represent human interests, but represent a particular local and parochial interest which has been globalised through their reach and control. In the same way the global environmental concern is 
being taken over and being made the reason for strengthening global institutions like the World Bank and the International Monetary Fund (IMF) which increase their global reach by taking over the language of underdevelopment, poverty, global environmental facility (GEF), Tropical Forest Action Plan (TFAP), ozone depletion, etc. The World Bank is not really a bank that serves the interest of all the world's communities. Its decisions are based on voting, weighted by the economic and political power donors. In fact this is the reason for new bondage based on development financing and debt burdens in the post-colonial era.

Another dangerous trend seems to be the use of the environment as a 'target and tool', as it happened in the Persian Gulf War, which has made global environmental governance a utopian concept. It may not be wrong to say that the era of cold war may soon be replaced by the era of environmental conflict: around, for example, the science and politics of acid rain and its effects on the environment; the act of creating, dispersing and depositing acid pollutants and their effect on surface waters, soils and regulations, buildings and humans. The point is not just teaching the likes of president Saddam Hussain a lesson but the so-called 'peacekeepers' assuming dictatorial powers. The consequences call for an introspection discovering a law within the conscience, giving heed to the inner voice which is ever calling man to love and do what is good and avoid evil.

The environmental question is a moral one and it is also a cultural one. If there are gaps or lapses in confronting this question, it is because of the exclusion and marginalisation of women in the socioeconomic, political and cultural spheres: the growing disparity between the genders. A woman is the last person who is consulted in any of the policy matters concerning environmental issues. But it is the woman who is struggling for survival in a harsh environment, fending for food, fodder, fuel and water for her family. A woman's responsibilities are tremendous but she does not have any power or control over her situation. Environmental movements the world over have identified the 'women's dimension' to the problem of greening the Earth. Women and nature are creatively associated with the maintenance of life. It is women's regenerative and intuitive power that endows them with unique insights into the diversity that marks the Earth's ecology and human communities. ${ }^{1}$ The role of women in conserving land and nature does not derive from conservationists and environmentalists. Man today is overwhelmed by the 'scientific temperament and rationalisation of life, has lost his intuitive power, a feminine quality in man. It is the cultural conditioning in which masculine characteristics like rationality, domination, possessiveness and aggressiveness dominate. Such domineering characteristics have dehumanised the world. 'Chipko' (to cling), a predominantly women's movement in the Himalayan villages, stopped the commercial felling of trees in their forests by encircling the trees and preventing contractors from destroying the forests. In the same way there is the 'Narmada Bachao Andolan' (Agitation to save the Narmada river valley) ${ }^{2}$ in Uttar Pradesh, a movement against the Tehri Dam construction, where the women in their own sincere and forceful way have prevented the destruction of nature. Ms Medha Pathak, the woman pioneering the 'Narmada Andolan' movement is a strong and determined woman who empathises with nature and the rural folk who would be uprooted if the project were implemented. Building a dam across the Narmada means a death knell for the rich plant and animal life in the valley and uprooting villagers because the villages will be submerged in water; it also means uprooting a people who have developed a symbiotic relationship with nature.

Environmental issues are close to the concerns of a Christian for two reasons. Firstly, a Christian is heavily engaged in the integration of faith and life by trying to live and promote gospel values. Secondly, at least 
some of the values underlying the environmental concern for a clean, safe and green Earth coincide with the basic Christian values in confronting the moral problem of social relationships and respect and responsibility for 'all of God's creation.

\section{Notes}

1 Mary, the Queen of all creation, according to the Byzantine theologians, is the fertile virginal Mother Earth that receives from the Spirit, not only at the Annunciation, but as a continued state of total surrender to God, the impregnation of God's word. The Blessed Mother by readily saying 'yes' to God, became a new woman to begin again a new creation. Her 'Fiat' was the total expression of her 'Faith'.

2 The Narmada dam project is a World Bank sponsored project for which $\$ 450$ million was sanctioned. But the Bradford Morse commission raised some questions on environmental aspects of the dam which were supportive of the assessments of the critics of the project in India. The activists' agitation is because of their environmental concerns and also because of the questions of resettlement and rehabilitation of the villagers and of land acquisition.

\section{References}

1 Barry Commoner, Making Peace with the Planet. Pantheon Books, 1990.

2 Jessica Tuchman Mathews (ed.), Preserving the Global Environment: the Challenge of Shared Leadership. Norton, 1991.

3 Choucri, Nazli. 'The Global Environment and Multinational Corporations', Technological Review, April 1991.

4 Vandana Shiva, 'Conflicts in Global Ecology', The India Magazine, August 1992.

\title{
Environmental Awareness: The Hindu Perspective
}

\author{
R. Vijayalakshmi \\ International Institute of Tamil StudiesTaramani, Madras
}

THE OLDEST RELIGION of the people of India is Hinduism. It is a religion which was not propounded by a single individual, but was evolved out of the developments spanning several millennia. It has the distinction that it has assimilated the unique features of all the ages through which it evolved. From the time of its appearance it has grown by adapting itself to its environment. Several works have come forth as an expression of its doctrines from the very beginning. But there is no single gospel for Hinduism as, say, the Bible is for Christianity. The Vedas, the Brahmanas, the Upanishads, the Puranas, the Ithihasas, all reflect the thought of Hindu religion. In order to discuss the environmental awareness from the Hindu perspective it is necessary to find out what these various scriptures have to say about this. Even before that it is necessary to define the concept of environmental awareness.

It may be said that environmental awareness consists of the efforts made by people to live in harmony with their surroundings. The land on which they live, the fauna and flora in it, the climate and the weather, water, light, all come under the category of environment. Even if the balance of people and their surroundings were to be disturbed in the slightest manner, there is scope for disharmony in human life. The 